\title{
Collaborative Cataloging of Spanish Industrial Heritage Assets through Teaching in Project Management Subjects
}

\author{
Juan Claver*D, Amabel García-Domínguez and Miguel A. Sebastián (D)
}

Department of Construction and Manufacturing Engineering, Universidad Nacional de Educación a Distancia (UNED), 28040 Madrid, Spain; agarcia@ind.uned.es (A.G.-D.); msebastian@ind.uned.es (M.A.S.)

* Correspondence: jclaver@ind.uned.es

Citation: Claver, J.;

García-Domínguez, A.; Sebastián,

M.A. Collaborative Cataloging of Spanish Industrial Heritage Assets through Teaching in Project Management Subjects. Sustainability 2021, 13, 10854. https://doi.org/ $10.3390 /$ su131910854

Academic Editor: Nicola Masini

Received: 26 August 2021

Accepted: 27 September 2021

Published: 29 September 2021

Publisher's Note: MDPI stays neutral with regard to jurisdictional claims in published maps and institutional affiliations.

Copyright: (c) 2021 by the authors. Licensee MDPI, Basel, Switzerland. This article is an open access article distributed under the terms and conditions of the Creative Commons Attribution (CC BY) license (https:/ / creativecommons.org/licenses/by/ $4.0 /)$.

\begin{abstract}
The cataloguing experience presented addresses two key challenges of cataloguing industrial heritage assets. On the one hand, despite their value and interest, some of these assets are little known and difficult to identify. Moreover, on the other hand, this heritage typology needs further promotion and valuation. In this context, collaborative cataloging responds to both challenges from its initial approach. Unlike cataloging tasks developed by small teams, involving many people throughout the territory allows to take advantage of the local knowledge of each participant. However, in addition, each participant contributes to the dissemination of the goods collected in the generated catalog. First in a passive way, when knowing the contributions of the rest of the participants. Secondly, actively, by disseminating the cataloging initiative developed among their contacts. This cataloguing experience has been developed with the students of the subject Environmental Project Management during the last four courses. The assets selected by the students (106) as case studies to develop a reuse project are shown in an open web map, which includes the narrated video presentation of the proposal developed for some of them (25). The obtained results contribute both the identification and promoting of this kind of assets.
\end{abstract}

Keywords: industrial heritage; cataloguing; collaborative; teaching; industrial tourism; environmental project management; reuse; manufacturing

\section{Introduction}

Due to its characteristics, the conservation of industrial heritage requires the reuse of its assets for new activities other than the original activity, linked, directly or indirectly, to a production process. Today, the industrial heritage is well valued by society, but the acceptance of industrial heritage as a typology of cultural heritage has been a slow process. The identification of its values and its justification has been the subject of numerous studies, developed from a wide variety of approaches. In this sense, the intense industrialization of some areas and their equally intense process of deindustrialization decades later, caused in a very short time, and especially in the cities, a large amount of goods and industrial landscapes of clear interest but without use and with many questions on how to assess and manage such a large and recent heritage sample [1]. Industrial heritage allows to preserve testimonies of relevant productive activities, and its assets may contain technological, scientific, historical, or aesthetic values, but it stands out compared to other heritage typologies due to its special capacity to offer identity to a community [2,3], and its analysis and management require innovative approaches [3]. The emphasis on the connections of this heritage with the memory and identity of the community is key to the social acceptance of initiatives for the conservation and reuse of these assets [4,5].

Thus, the adaptation projects of old buildings of industrial origin for new uses is actually a common practice [6]. In the same way, many authors study the opportunities of this type of action and the best methodologies and practices to carry them out within sustainable development approaches [7-10], while other lines of research related to this 
typology have been consolidated, such as the industrial tourism [11-14]. In this way, in recent years, industrial heritage has been consolidated as a valuable resource for local development [15] and for the economic reactivation of both urban and rural areas in the post-industrial era. The large areas affected by the industrialization process and subsequent deindustrialization give industrial heritage great potential for territorial regeneration in some regions, becoming a reterritorialization tool capable of even modifying the identity of the territory [16]. Since the 1990s, acceptance and sensitivity towards industrial heritage is a reality throughout Europe [5,17], a trend to which Spain joined with some delay [5] and in which the emergence and consolidation of industrial archeology as a discipline had great importance $[18,19]$. Despite the current context, which is favorable for the protection of this patrimonial typology, it is important to pay attention to the perception by society of these assets in order to reinforce the identity bond without over-prioritizing mainly economic aspects [3]. Sometimes, the social dimension of industrial heritage is neglected, prioritizing economic and environmental aspects, which has bad consequences on the sustainability of regeneration processes [20].

Recent studies analyze this problem from new interesting approaches, such as the negative perception that industrial tourism can generate in some communities [21-23], the interest of citizen participation as a strategy for the social acceptance of actions to recover these assets [24,25], and even for the voluntarily monitoring of the industrial heritage [25]. It is also very interesting to observe the convergences and divergences of research on industrial heritage in different territorial and cultural contexts [26].

Assuming this need and being consistent with the consideration of heritage, it is important that the characteristics of value that grant said heritage value are not attacked when adapting the assets to the new use $[27,28]$. Given the variety and heterogeneity of characteristics of potential value that industrial heritage assets may possess, the authors of this work consider especially useful the approaches that support the valuation of these assets in multi-criteria decision-aid tools and techniques [10,27-30]. However, there is a previous question, how to assess what these valuable characteristics are without knowing the sample of goods that make up the typology? Any assessment requires a context, and that context can condition the results of the assessment. In this sense, knowing the sample of goods that make up the industrial heritage provides a significant part of the context necessary to assess the interest of a specific asset.

Highly recognized international consensus, such as The Declaration of Amsterdam [31] and The Niznhy Tagil Charter for the Industrial Heritage [32], remark the importance and the need to identify the set of assets included in the typology studied. An identification that must be registered following specific criteria of the typology [33,34].

When analyzing a good of a certain type, it is necessary to know the main characteristics of said type, derived from those that mostly present qualifiable assets as part of said typology [35-37]. This is important in order to be able to assess both the presence of those characteristics in the particular good analyzed and their degree of uniqueness. This last aspect can only be assessed in reference to the sample of existing goods. The features of special interest of a given asset are so in relation to their exclusivity with respect to other similar assets. Otherwise, without knowing the sample of goods a special value may be given to a good that in reality can be quite common within the typology.

Thus, the identification and cataloging of assets represents an initial task within the process of protection of this built industrial heritage, not a final one [38], that must be tackled in an ambitious manner, trying to make the amount of identified assets as close as possible to the existing set. In typologies such as industrial heritage, this represents a challenge, given the large number of existing immovable assets and the concentration of many of them in short periods of time, such as the first and second industrial revolutions. The location of some assets or the short time they were active are examples of some of the factors that can make some goods of great interest little known outside the local level. For this reason, the larger the territory that the cataloging initiative wants to cover, the greater 
the difficulty of being able to bring to light these less known but existing examples in the different regions.

It is in this context that the collaborative cataloging strategy has special potential. There are collaborative or cooperative cataloging initiatives, but more associated with intangible assets and mainly oriented to databases in which contents in digital formats are managed [39-41]. On the contrary, the cataloging experience analyzed in this work is oriented to the built industrial heritage. It is, therefore, a very different approach and in which the identification of new assets requires work in the field by the participants in the cataloging initiative. In addition, the geolocation of movable property offers opportunities for the dissemination and promotion of heritage that are considered to have great potential [42]. In this sense, constant technological development continuously offers new opportunities, even for the detection of goods [43].

The cataloging initiative analyzed in this work is focused on the industrial heritage of Spain. Therefore, the territorial scope to be covered is wide, so the next challenge may be the formation of a group or team with a sufficient presence throughout the entire territory. In this sense, this cataloging experience arises from a practical activity developed in the Environmental Project Management course at the National University of Distance Education (UNED), in which students must select a good of this type to develop a reuse project. In this way, students are who each year identify a new set of goods that are later incorporated into the collaborative catalog.

The special characteristics of the UNED distance education model are understood as keys to the success of this experience. The student body is scattered throughout the national territory and the university has a network of 60 Territorial Associated Centers and numerous support classrooms that give it a great presence throughout the territory. In this way, unlike universities linked to a much more limited territorial scope, the UNED has the structure needed to channel an experience like this through the activities carried out by its students.

The design of teaching experiences focused on the study of industrial heritage assets is considered by the authors to be very interesting in the field of technical education, both because of the scientific-technological interest in this type of asset and because of the contribution of this type of activities to the dissemination of industrial heritage. A clear example, and probably the most recurrent, of the teaching potential of practical activities based on industrial heritage goods in the context of technical teachings is the recreation of industrial, movable or immovable assets, using computer-aided design tools [44-46]. This work explores the potential of these heritage issues in subjects from a different area of knowledge, such as project management. Thus, since the cataloging initiative arises from a previous teaching experience, this work also analyzes the interest and impact that the strategy designed around the study of industrial heritage assets has had in the teaching context.

This teaching experience has, like the cataloging initiative launched, a collaborative approach. Students must select industrial heritage assets and propose reuse projects. These projects are developed individually, but then works must be presented by their authors and the proposals are discussed by students and teachers. This second phase is the most interesting from the teaching point of view, and in it students can share experiences and approaches, and construct new knowledge together [47], which is aligned with the concept of education for sustainable development (ESD) proposed by the UNESCO $[48,49]$ and which contributes to greater student motivation [50]. At the same time, from the point of view of the European Higher Education Area (EHEA) [51], teacher-student interactions are identified as a key way to generate knowledge in university education [52]. This approach is especially appropriate in engineering project subjects, not only because of its practical and applicative nature that is more conducive to active learning methodologies, but also because of the possibility of learning in the way in which other students face the same problem and of the solutions they propose [53-55]. Collaborative learning provides strategies aligned with the teaching model defined by the EHEA for project subjects [53] and also 
provides valuable skills, such as team work abilities, which are valued by companies and can represent competitive advantages within the job market [54,56,57]. In addition, the new information and communication technologies offer multiple possibilities for collaborative learning [58], reducing the traditional limitations of distance education models for this type of strategies compared to classroom education.

Thus, this work presents two independent experiences in their development but intimately related since both have been conceived and designed in a joint and integrated way. Both provide feedback and support each other, and simultaneously contribute to Goal 4 (Quality Education) and Goal 11 (Sustainable Cities and Societies) of the Sustainable Development Goals of the European Union [59].

In this way, this work presents an investigation in educational innovation based on the collaborative learning of students through the development and sharing of action projects in industrial immovable assets, and whose results are used for the dissemination and promotion of industrial heritage through the creation of a collaborative and public catalog. The possibility offered by the UNED teaching model to involve a significant number of students distributed throughout the national territory in the identification of assets of potential interest, is considered very attractive. The possibilities of this type of teaching strategies in the promotion of industrial heritage are discussed through the results of the experience developed during four academic years, understanding this time as sufficient to observe certain trends, comment on the results, and point out new actions in the future.

\section{Materials and Methods}

The authors of this work have been developing different initiatives for the cataloging of industrial real estate assets of industrial heritage in Spain. The motivation for these cataloging attempts arises from the idea of developing a methodology to guide industrial property reuse projects towards new uses that are not very aggressive with their heritage values. That is, activities that require little adaptation of the asset or an adaptation that does not affect the parts identified as valuable. At that time, it was considered that the catalogs available on goods of this type, the initial catalog of the National Plan for Industrial Heritage [60] and the Minimum Catalog of the International Committee for the Conservation of Industrial Heritage [61], were not representative of the real sample of goods and, therefore, of the typology that was to be studied. The catalog elaborated by DOCOCMOMO Ibérico about the industrial assets of the modern movement was also considered [62], and all the industrial assets protected as Assets of Cultural Interest (BIC) were identified, but the sample was still not broad enough to be understood as representative of the typology.

The authors considered that in order to achieve the final objective of being able to assess the impact of a reuse action on the industrial heritage value of a particular asset, the valuable aspects in this type of goods should be previously established. Moreover, at the same time, to value an asset of this type it was considered necessary to know enough about the real sample, both to be able to understand the features of these goods in the national territory and in each of its regions, and to be able to contextualize each particular element within the sample and to assess their uniqueness. In this way, a first catalog was made in which 1354 goods were identified, applying 49 classification criteria to all of them. From the combination of these criteria, numerous analyses of a different nature were derived that sought to characterize the typology in each region and in the entire national territory [63]. The main results related to the cataloging of assets were collected in a book, which is the one that the students of the subject use as a reference for the development of the activity [64]. The results of the research related to the estimation of the heritage value of the assets and the identification of the most respectful uses with their conservation was addressed by adapting the Hierarchical Analytical Process [65] as a tool to aid decision-making. This part is provided to students through publications derived from the research $[27,28]$, in which the key aspects, such as the set of values considered, are exposed. 
At the same time, the authors have continued to work on improving the catalog, both in relation to the classification criteria applied to the sample of goods [35] and to increase the number of goods identified. Regarding the identification of new assets, the authors began a process of updating and reviewing the catalog through partial cataloging works focused on specific territories [66-70]. Through the experience of these works of identification and cataloging of assets, the authors encountered many difficulties in identifying some little-known but very interesting and valuable assets, especially in rural areas. From that perception, the possibility of launching collaborative cataloging initiatives began to be considered, thinking of taking advantage of the knowledge of the local heritage that only the inhabitants of each territory have, as a result of the cultural heritage transmitted by previous generations.

The next question was with which local agents this collaboration could be established. It is then when the idea arises of developing a pilot experience in the subject of Environmental Project Management, proposing to the students a practical activity based on the development of a project for the reuse of an industrial heritage asset in their environment. The unique characteristics of the UNED, with the presence of students throughout the national territory, offered a unique opportunity. On the one hand, each academic course could provide new collaborators distributed throughout the territory, who could contribute their knowledge of the local level to identify new assets. On the other hand, the teaching experience on industrial heritage would contribute each academic year to promoting the values of industrial heritage among a new group of students, who in turn could contribute to the promotion of this typology among their contacts.

In this way, the collaborative cataloging experience described in this work is developed as part of the teaching activities of the Environmental Project Management [71] course taught by the authors at the UNED. It is a compulsory subject of 5 ECTS (European Credit Transfer and Accumulation System) [72] taught in the fourth and last year of the Degree in Environmental Sciences. The contents of this subject are aimed at acquiring management skills for the works and resources involved in projects of environmental interest.

Students are offered a voluntary itinerary of three practical activities of continuous evaluation that allow them to obtain $40 \%$ of the final grade. The first two activities are short and have little weight in the final grade, and they try to put into practice some specific techniques. They are identified as Continuous Evaluation Activities 1 and 2 (CEA-1 and CEA-2). The third of them (CEA-3) involves the development of a complete practical case and represents $30 \%$ of the final grade. In this activity, students have to develop a proposal for the reuse of an industrial immovable asset for a new activity, applying the techniques studied during the course.

These kinds of projects represent a context of maximum interest for project management subjects, since they must define and execute a specific and tangible solution, which requires simultaneously considering aspects of varied nature. These are, therefore, complex problems, and even more when the definition of a solution is affected by the initial conditions of a previous activity and when it is necessary to preserve and protect parts considered valuable from a heritage point of view and adapt others to new needs. Thus, the large number of conditions and starting limitations that exist in the type of projects that students are asked to carry out in the third activity, represent very interesting situations in a teaching context.

The Industrial Heritage assets are present throughout the territory and allow us to know the productive activities that existed in the different regions and whose facilities are, in many cases, in the greatest abandonment and condemned to disappearance. The impact of industrial activity on the environment and the landscape can be observed through very different types of productive facilities. Mines, salt flats, transport infrastructures such as railways or canals, and facilities aimed at generating energy such as dams, are just a few examples. The emergence of new population centers around new industries, as well as the growth of existing cities around certain industries, is another clear consequence of productive activity in the territory. 
Until the arrival of the steam engine, the dependence on natural resources as a source of energy for production processes, led to the appearance of production facilities in environments of special natural value. The elevated locations of the windmills to maximize exposure to the winds, or the locations in the river channels and points of the coast in the case of the hydraulic mills and the tide mills, exemplify these situations. These special locations in natural environments have motivated that some actions to recover these assets have been oriented towards their conversion into environmental interpretation centers. On the other hand, industrial activity is accompanied, especially since the Industrial Revolution, by a certain level of aggression to the environment. Aggression derived from productive activity, but which often does not disappear or attempt to correct when the activity ceases.

With all this, the reuse projects on this type of assets have an environmental component in which the graduates in Environmental Sciences can and should contribute their vision, so it is understood to be an interesting topic for the development of a practical activity in the subject of Management of Environmental Projects.

Thus, students are asked to select an industrial asset from their immediate environment that they consider of interest. The selected assets can have building scale, for example a factory, and they also can have a larger scale, allowing students to speak of industrial landscapes. Salt flats, mining areas, large sets of industries related to each other, sets of mills, both windmills and hydraulic mills, or the groups formed by some factories and the workers' houses are some examples of this larger scale.

After selecting the good chosen as a case study for the development of the activity, the students must address the following points.

- Visiting the property physically: taking 10 photographs that they consider representative and that allow an initial characterization of its fundamental parts.

- Justify the choice of the property: identifying its interest and its main characteristics, defining its current state and the main problems caused by its deterioration that have been detected and that are to be corrected.

- $\quad$ Propose and justify the action proposal: motivation, needs, objectives, etc.

- If applicable, analyze the economic viability of the proposal, identifying possible costs and incomes, and composing the corresponding cash flows.

- Define the action proposal initially, indicating at least:

- Schematic plans, not detailed, of the proposal (by computer or by hand).

- Identification of the necessary works, estimation of their durations and their planning and scheduling. Determination of the total duration of the project.

- Estimation of the necessary resources and the costs of the project.

In short, the activity proposed to the students aims to make an initial approach to a proposal for action, not to develop a detailed final solution. The activity wants to serve to reflect on the different contents studied throughout the course and put them into practice through a practical case that the students themselves will define and guide according to their criteria, interests, etc.

Figure 1 shows the development of the proposed activity during the course (in the upper half) and its subsequent continuity in the collaborative cataloging initiative in which students can participate (represented in the lower part of the figure). The upper part of the figure shows the main stages of the proposed activity, being able to distinguish three situations in relation to the exchange of information between each student and the teaching environment, formed by the rest of the students and the teachers, according to whether or not there is feedback on the work done. An icon of a house identifies those stages based on each student's personal work. An icon with information inputs towards the university identifies the stages that require each student to share their progress in the virtual course of the subject in order to share them with the rest of the students and with the professors, an answer not being necessary in most cases to continue with the activity. Finally, an icon that represents both inputs and outputs of information shows the stages in which a debate 
is opened around the work carried out by the students and in which they will receive feedback from both the rest of the students and the teachers.

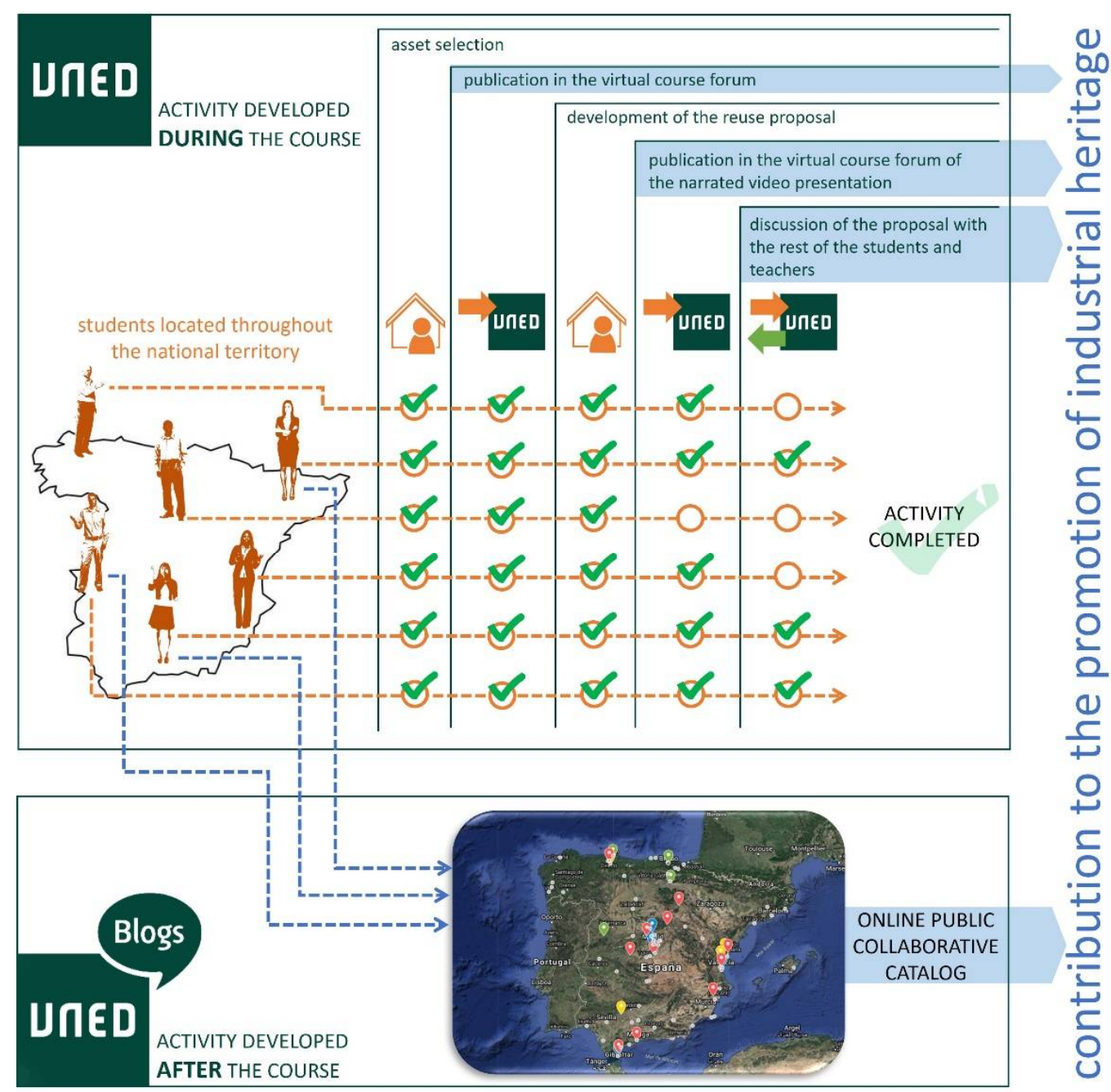

Figure 1. Main stages of the proposed activity (CEA-3) during the course and incorporation to the collaborative catalog.

As shown in Figure 1, students must complete all the programmed stages for the activity to be understood as completed. Subsequently, those who have completed the activity can choose to participate in the collaborative cataloging initiative. The idea of creating a collaborative repository based on student work arose in the 2017-2018 academic year, the first time that this activity on industrial heritage assets was proposed to students. Since then, different ways of carrying out this initiative have been studied, being at the end of the 2020-2021 academic year when it was decided to launch it with the idea of continuing it during the next courses, growing year after year with the contributions of the students. During the same course, a university blog was created to give visibility to the activities carried out by the UNED Industrial Heritage Work Team [73] of which the authors are members, and which is integrated into the Industrial Production and Manufacturing Engineering Research Group (IPME) [74] of the Department of Construction and Manufacturing Engineering at the Technical School of Industrial Engineering. With this, an adequate channel was available to include and promote the collaborative catalog that was to be created.

Thus, all students who completed the activity during the 2017-2018, 20108-2019, 2019-2020, and 2020-2021 academic years received at the end of the 2020-21 academic year an email explaining the characteristics and objectives of the cataloging initiative and asking 
for their participation, which in any case was voluntary. The students who decided to participate had to respond by providing written authorization to publicly share the narrated video presentation of their reuse proposal, as well as indicate the GPS coordinates of the selected asset and provide the presentation file. Both the use of tools for geolocation of assets, such as Google Maps, and access to multimedia content, such as video presentations, are resources used in significant initiatives to promote industrial heritage [75].

By having the GPS coordinates of the locations of the identified assets, it was considered that the most interesting way to disseminate the sample of assets selected by the students was an online and interactive map [76]. For this, the Google My Maps application was used [77]. As shown in Figure 2, the map created includes two types of elements. On the one hand, using small circular markers, it shows the locations of all the goods identified through the works carried out during the four courses considered. On the other hand, those elements for which the authors of the works decided to share the video of their narrated presentation are shown with larger location icons, in this case differentiating the academic year by the color of the icon.

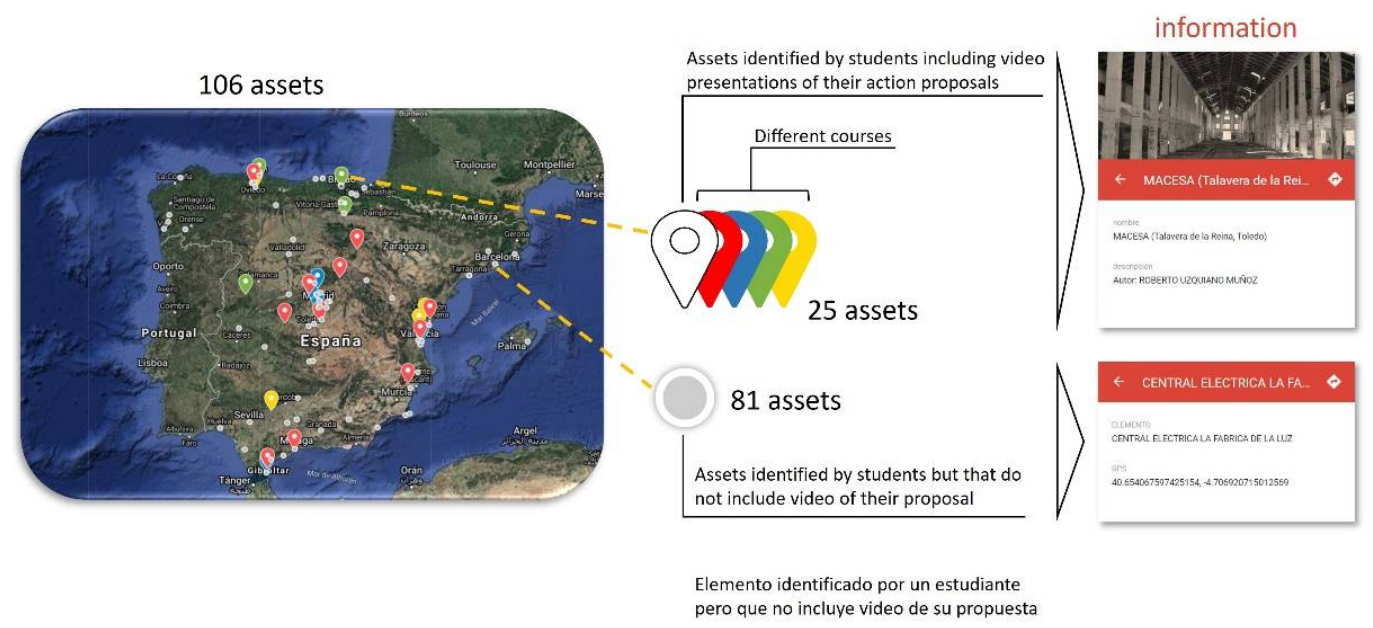

Figure 2. Main information provided by the collaborative map.

For both types of elements, information is provided regarding their name and nature, as well as their geographical location. In the case of the elements for which there is a video of the reuse proposal made by the student, said recording, previously uploaded to YouTube, can also be accessed.

As indicated in Figure 1, both some of the stages of the activity proposed to the students and the collaborative catalog that includes their contributions are considered valuable contributions for the promotion and enhancement of industrial heritage assets. The UNED has a clear added value for an initiative like this compared to other universities, since its students are not located in a specific region but are scattered throughout the national territory. This characteristic makes it possible to identify a more heterogeneous and varied sample of elements. A national approach to this typology makes it possible to learn about production traditions typical of regions other than our own, as well as avoiding excessive repetition in the elements selected by the students, something inevitable in smaller territory contexts.

The coincidence or not of the goods identified with the goods included in the main catalogs of industrial assets published in Spain $[60,61]$ will make it possible to assess the capacity or not of this type of initiative to bring to light new goods of interest. In this sense, it is also interesting to analyze whether the assets identified by the students may or may not be understood as assets with a certain heritage value. The authors consider essential the incorporation of industrial heritage content into the teaching of technical education, being in fact professors of the only university degree specifically oriented to industrial heritage that is currently offered in Spain [78]. Nevertheless, it is understood that although the students of the Environmental Project Management course have a very interesting 
profile to work on projects for the reuse of immovable industrial goods due to their impact on the environment, they may lack certain prior knowledge that enables them to assess the patrimonial interest of the goods of this type.

Finally, in addition to the interest that this initiative has from the point of view of the dissemination, enhancement, and knowledge of industrial heritage assets, the collaborative map created also represents a very valuable source of starting information for students of the subject in the following courses, since it collects a significant number of examples to illustrate both the type of assets that can be studied in the proposed activity and the responses given by students from previous courses.

\section{Results}

This section analyzes the collaborative cataloging initiative carried out with the students of the Environmental Project Management course. The direct results of the catalog are studied in relation to the capacity of collaborative strategies for the identification of new goods and their promotion among society. However, indicators of the impact of the activity proposed to students in the teaching framework are also identified. In addition, the possible extrapolation of the proposal described to other subjects in the Engineering Projects area is briefly discussed.

\subsection{Initial Considerations on the Development of the Activity Proposed to the Students}

During the four academic years considered, the activity described was carried out by a total of 157 students. Figure 3 shows the number of students enrolled in the subject each course and the number of them who carried out the voluntary activity from which the collaborative cataloging initiative described in this work derives. As can be seen, participation follows an upward trend, reaching almost half of the enrolled students in the last year. On the other hand, the global participation throughout the first four years in which the activity has been proposed to the students rises to $28 \%$ (157 students of the total of 561 enrolled carried out the activity).

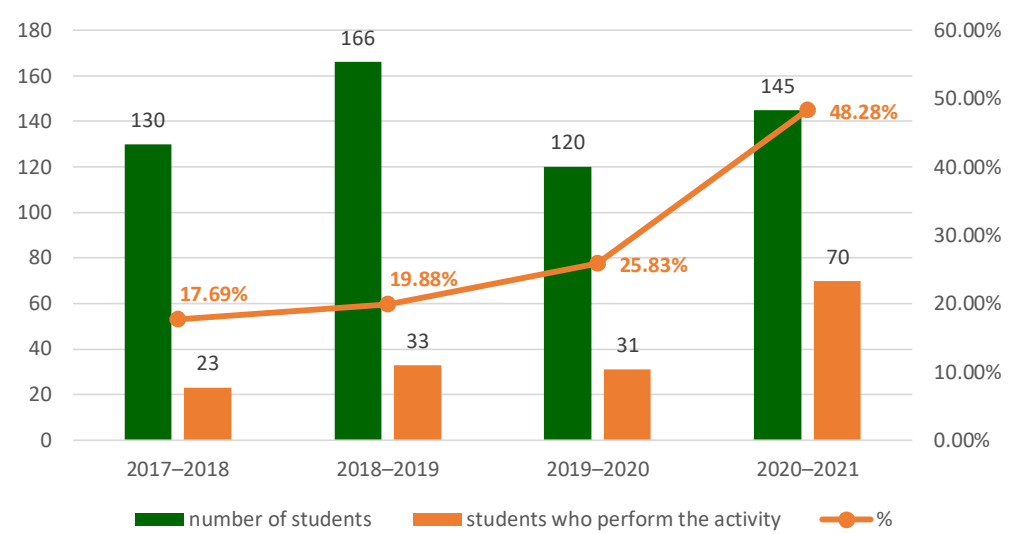

Figure 3. Student participation in the proposed activity (CEA-3).

It should be noted that not all the assets selected by the students in the framework of the proposed activity in the Environmental Project Management course were considered in the collaborative cataloging initiative. As shown in Figure 4, some of these assets were discarded, so the total number of effective contributions to the collaborative catalog decreases with respect to what was expected in view of the participation represented in Figure 3. Except in the case of the first academic year, in the rest of the courses there is a trend of around $20 \%$ in relation to works that were not considered in the cataloging initiative. The fundamental reason for exclusion corresponds to cases in which the students chose assets without an industrial origin, but that were accepted as case studies because they were interesting from the point of view of environmental projects and, therefore, for the subject. Within these cases, old military installations were the most common typology. 


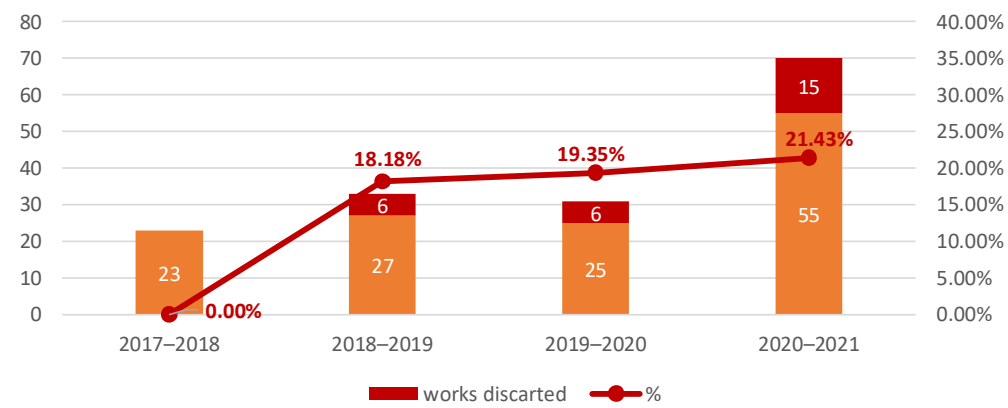

Figure 4. Reuse projects discarded in the cataloging initiative due to the non-industrial nature of the assets.

These 28 discarded works reduce the number of reuse projects developed by the students considered in this cataloging initiative to 130. However, in terms of cataloging, duplications in the selection of assets as case studies must be accounted for as a single element. In this sense, only three goods were selected by more than one student, and in all cases the elements were repeated only once. This is the case of the Getares Whaling Factory, in Algeciras, the Vinival Wineries, in Alicante, and the Factory of the Clesa company, in Madrid. Thus, the total number of assets considered in this cataloging initiative rises to 127.

The selection of a real asset as a case study for the development of the proposed activity, allows to identify a certain sample and geolocate its elements. This information is already valuable in itself. However, as noted above, some students voluntarily participate in the cataloging initiative by contributing the video presentation of their reuse projects. These contents, although heterogeneous, provide greater knowledge of the goods through the graphic information included in the video presentations and the comments made by the students about the selected asset. Figure 5 graphically shows the proportion of students who in each course have expressed their agreement to share the video presentation of their project, incorporating it into the collaborative map. For this, the number of projects indicated in Figure 4 are taken as a reference in each academic year. As can be seen, except for the second year, the trend is around $20 \%$.

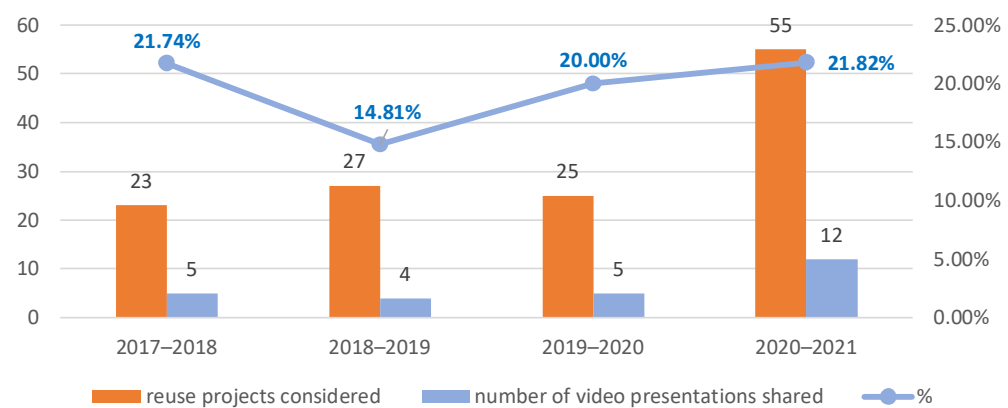

Figure 5. Percentage of assets with video presentations shared by students for their incorporation into the collaborative catalog.

It is worth mentioning, three of the positive responses to the invitation sent to all students to participate in this cataloging initiative were not included in the collaborative map. The reason was the non-industrial nature of the goods selected as a case study. This decision is important, as it makes clear the boundary between the teaching activity carried out during the course and the cataloging initiative. For the activity, students are proposed to work on industrial heritage assets, but even though the majority opt for assets of this type, it is not a mandatory condition, as long as the case studies are interesting from an environmental point of view. On the contrary, the cataloging initiative is specifically oriented to this type of goods, so non-industrial goods cannot be included.

In this sense, this initiative does not seek to identify and catalog industrial assets in general, but rather industrial heritage assets. Therefore, the selected goods must have a certain cultural value since their industrial nature is not enough. Figure 6 shows the 
number of goods selected by students that can be understood as valuable from the point of view of industrial heritage and the percentage they represent with respect to the total projects considered each academic year. It is possible to observe a clear downward trend in the last two years.

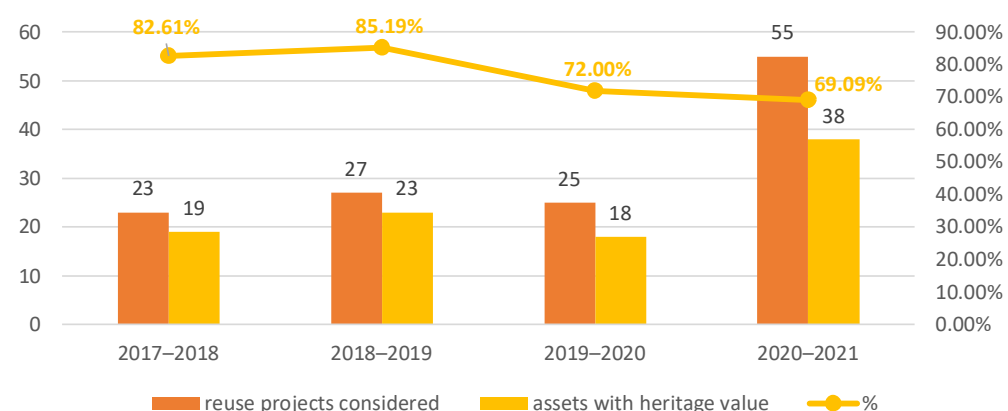

Figure 6. Percentage of assets with heritage value.

If this analysis focuses on the goods for which the students shared the video presentation of their reuse project, the downward trend is noticeably accentuated during the last year, as shown in Figure 7.

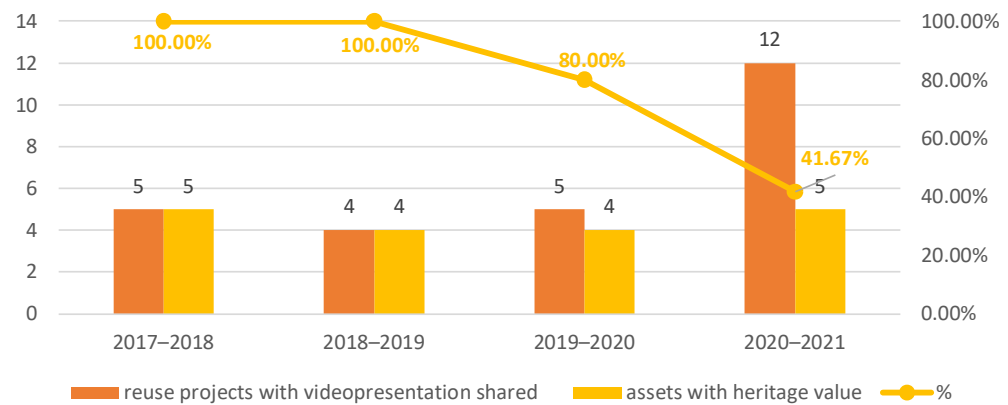

Figure 7. Percentage of assets with video presentation shared and heritage value.

As previously mentioned, the students of the Environmental Project Management course, taught in the Degree in Environmental Sciences, have a suitable profile to analyze the special relationship of industrial goods with the natural environment and explore sustainable new uses. However, on the other hand, their profile does not guarantee the ability to assess the patrimonial interest of this type of assets. The trends observed in Figures 6 and 7 are an example of this. Although projects for the reuse of industrial heritage immovable assets are considered a very interesting practical context for the objectives of the Environmental Project Management course, the specific contents of this heritage typology are not covered by the curriculum of this subject. In this way, bibliographic references are provided to students to offer them a first approach to the characteristics of the typology $[27,28,35,64]$. However, in view of the observable trends in Figures 6 and 7 , it seems clear that these resources are not achieving that goal. In this sense, in the conclusions section, corrective actions will be pointed out for the next course.

This situation has two independent interpretations. One in the teaching context of the Environmental Project Management subject and another in the context of the collaborative cataloging initiative that derives from the practical activity proposed to the students. The teaching objectives of the subject and the cataloging initiative are related through the practical activity proposed to the students based on the reuse of industrial heritage assets. However, despite this relationship, they are independent and asynchronous realities, and the role of industrial heritage in each case is very different. Figure 8 tries to graphically show the different importance that the link of the selected assets with the industrial heritage has in the teaching context of the subject and in the context of the cataloging initiative. 


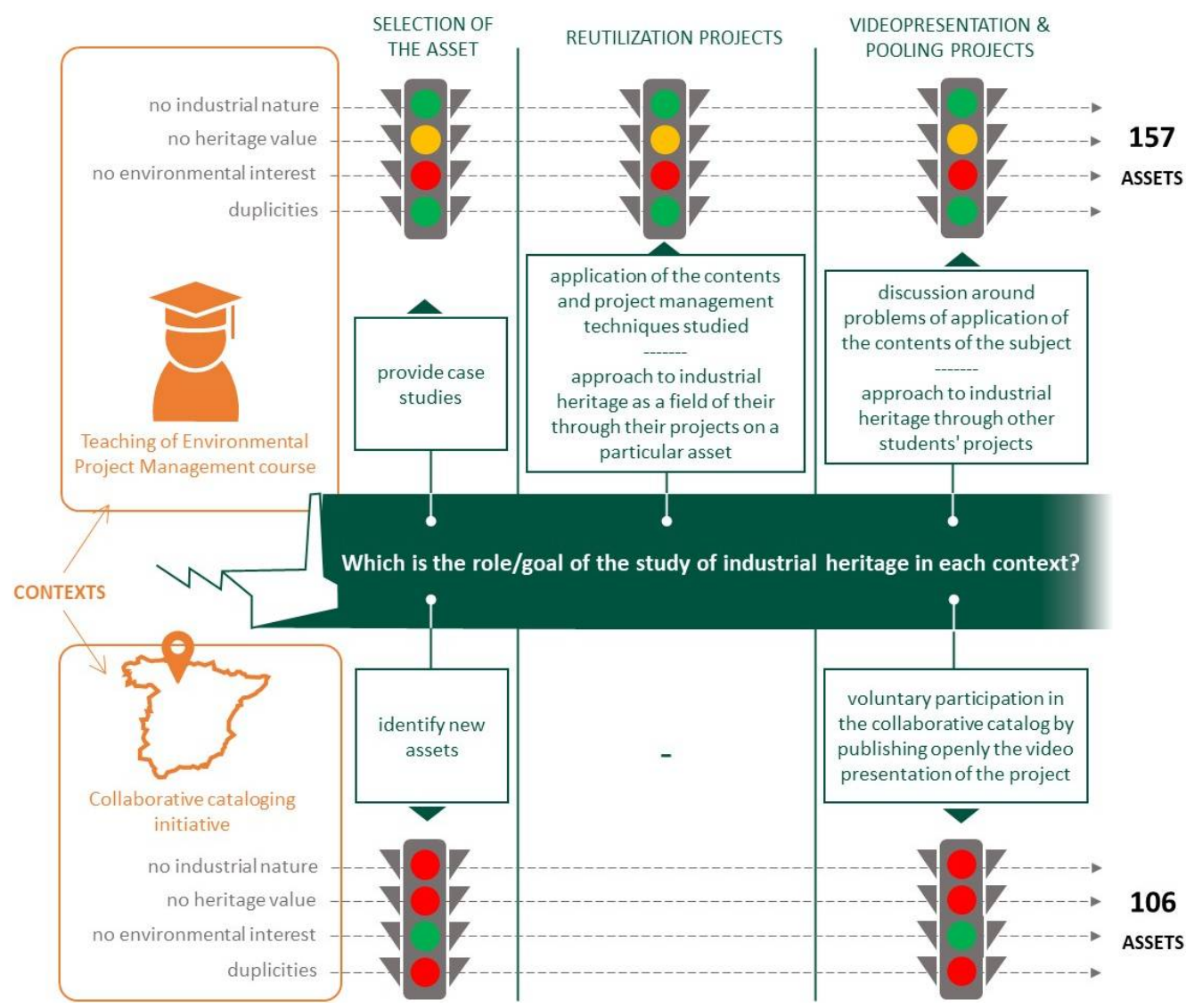

Figure 8. Differences between the difficulties that may arise in the teaching context and in the cataloging context from the activity proposed to the students, and influence of industrial heritage as a subject of study.

In this way, as shown in Figure 8, students working on assets of another type, such as old military installations, fortresses, or religious complexes, do not represent a problem within the framework of the subject and the selected assets can be case studies of great interest for the teaching objectives. However, in relation to the cataloging of industrial heritage assets, these works will not contribute any new element. Furthermore, when the selected asset is of an industrial type, but it does not have patrimonial value, it will be equally impossible to include it in the catalog because it does not conform to the nature of the sample. However, in addition, in this case the lack of heritage value also affects the educational context, whether they are industrial assets or not. This is due to the greater difficulty of acting on assets with valuable parts that must be protected and the interest of these situations in the context of a project management subject. On the other hand, the environmental interest of the selected asset according to the environment in which it is located and its relationship with it is critical for the objectives of the subject and is a key aspect to monitor from the teaching point of view. However, it is not relevant in terms of the cataloging initiative, which is focused on other characteristics. Finally, that two students develop their project on the same good is not a problem in the teaching field, and it may even be interesting to compare alternatives. On the contrary, in terms of cataloging the same item cannot count twice.

Due to all this, the number of assets on which the students relied to develop their projects for the proposed practical activity is significantly higher in the teaching context (157) than the number of assets that have been considered in the cataloging initiative (106).

\subsection{About the Sample of Identified Assets}

Figure 9 identifies the assets included in the collaborative catalog that were already identified in some of the main cataloging initiatives of Spanish industrial heritage available 
to students. On the one hand, the initial catalog of the National Plan for Industrial Heritage [60] and the Minimum Catalog of the International Committee for the Conservation of Industrial Heritage [61], as the most representative examples of the cataloging of this typology in Spain. On the other hand, the catalog collected in the complementary bibliography proposed to the students of the subject [64], the main resource of consultation for the development of the activity. Figure 9 also shows the elements included simultaneously in more than one of these catalogs.

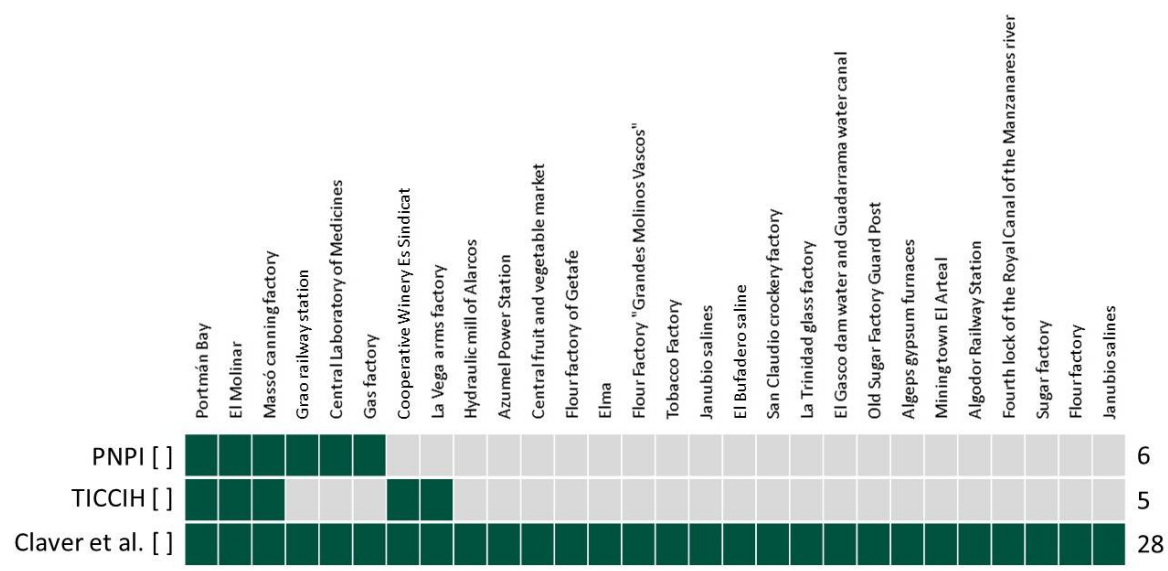

Figure 9. Assets previously included in the main catalogs considered.

Thus, with respect to the 106 assets currently included in the collaborative catalog, the possible influence of these previous references on the selection of assets by students is low in the case of the National Plan and TICCIH Catalogs (5.6\% and $4.7 \%$, respectively). Moreover, in the case of the recommended bibliography this possible influence is moderate, with $26.4 \%$ of the goods included in the collaborative catalog also included in the cataloging of the recommended bibliography. This percentage also coincides with the total of assets previously included in any of the cataloging initiatives indicated, as shown in the first graph of Figure 10.
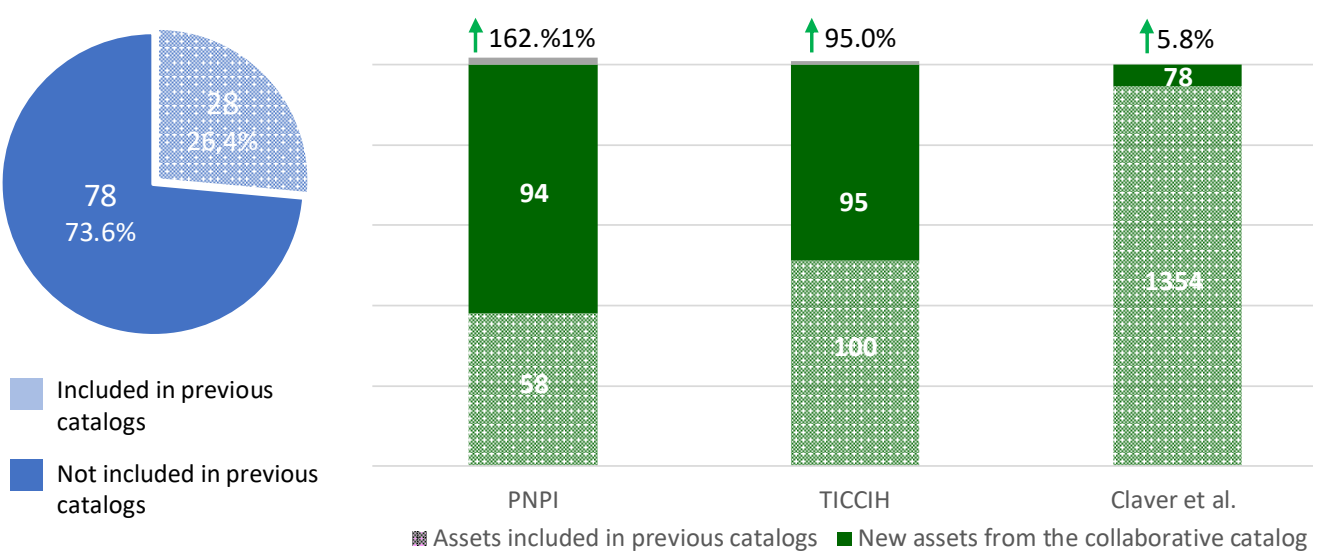

Figure 10. Influence relationships between the collaborative catalog and the previous catalogs considered.

However, it is interesting to carry out an initial analysis in the opposite direction, that is, to what extent the set of goods identified in the collaborative catalog would have the capacity to expand the samples of the previous catalogs considered. The PNPI Initial Catalog identified 49 assets, expandable to 58 considering the actions carried out between 2002 and 2010, referred to in the 2011 Plan report. The TICCIH Minimum Catalog includes 100 assets, and the catalog included in the basic bibliography includes 1354 elements. The right part of Figure 10 shows the possible impact of the sample made up of the students' work and shown in the collaborative catalog if these goods were included in the previous 
catalogs considered. This growth referred to the National Plan and TICCIH catalogs is very high, but mainly because they are not very large samples. The number of industrial heritage assets is high and it is a typology that will continue growing in the future, so the authors understand that the cataloging initiatives of this typology must be very broad in terms of the number of assets considered. It is from this point of view that collaborative cataloging strategies make sense. For this reason, the capacity of this kind of approaches to increase the number of identified assets must be evaluated in relation to samples that are already large, such as that included in the complementary bibliography proposed to students for this activity [64]. As shown in Figure 10, in this case, the growth derived from the incorporation of new goods from the collaborative catalog would be $5.8 \%$, which is valued positively taking into account the size of the starting sample.

Figure 11 shows the territorial distribution of the goods included in the collaborative catalog. The first map shows the distribution of goods in each of the Autonomous Communities. In all of them, the cataloging initiative allowed the identification of some asset. The second map is oriented to the distribution in the provinces. Although in this case it is possible to identify some territories for which no asset was identified, in general a good distribution of assets can be observed throughout the entire national territory.
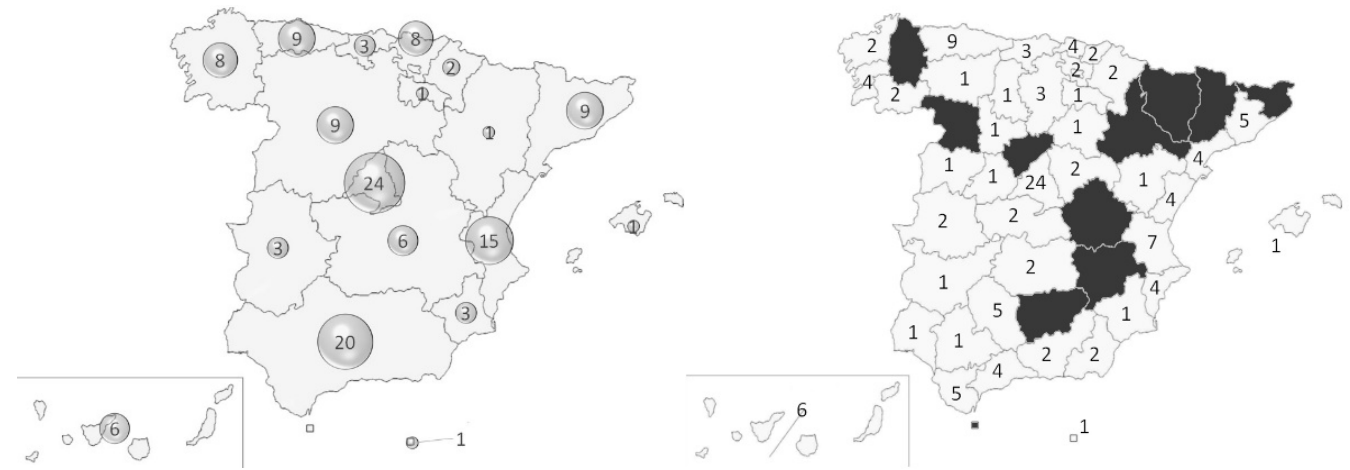

Figure 11. Territorial distribution of the assets included on the collaborative catalog.

This is a key aspect if the study of typology is wanted to be approached at the national level. Furthermore, only a university like the UNED, with a structure of 60 Territorial Associated Centers distributed throughout the country and with students in all territories, is capable of addressing a collaborative experience with students with such a broad territorial scope.

\subsection{About the Impact of the Initiative on the Teaching of the Subject}

From an approach focused on teaching, a first aspect of interest in the context of the Environmental Project Management subject is to confirm the environmental interest of the case studies selected by the students for the development of the proposed activity. As previously stated, the choice of industrial heritage as a field of study in this activity is due to the special relationship that many of the assets of this type have with the environment and the additional interest to act on assets with patrimonial heritage values to be protected. However, the choice of Industrial Heritage as typology for this practical activity should not penalize the presence of aspects of environmental interest but rather complete them, since these are the most interesting for the subject.

Figure 12 allows us to make some observations about the interest of the selected assets from the environmental and industrial heritage point of view, both independently and jointly. It can be seen that 87 of the 130 goods considered in this study had a certain degree of environmental interest, which represents $66.9 \%$, while 98 goods had a certain degree of industrial heritage value, which represents a percentage higher, $75.4 \%$. This shows greater attention to the specific selection criteria of the activity, relative to the proposed typology of assets, than to the environmental approach of the subject and the degree. This aspect 
will try to be corrected in the next academic years by including new guidelines for carrying out the activity in this regard.

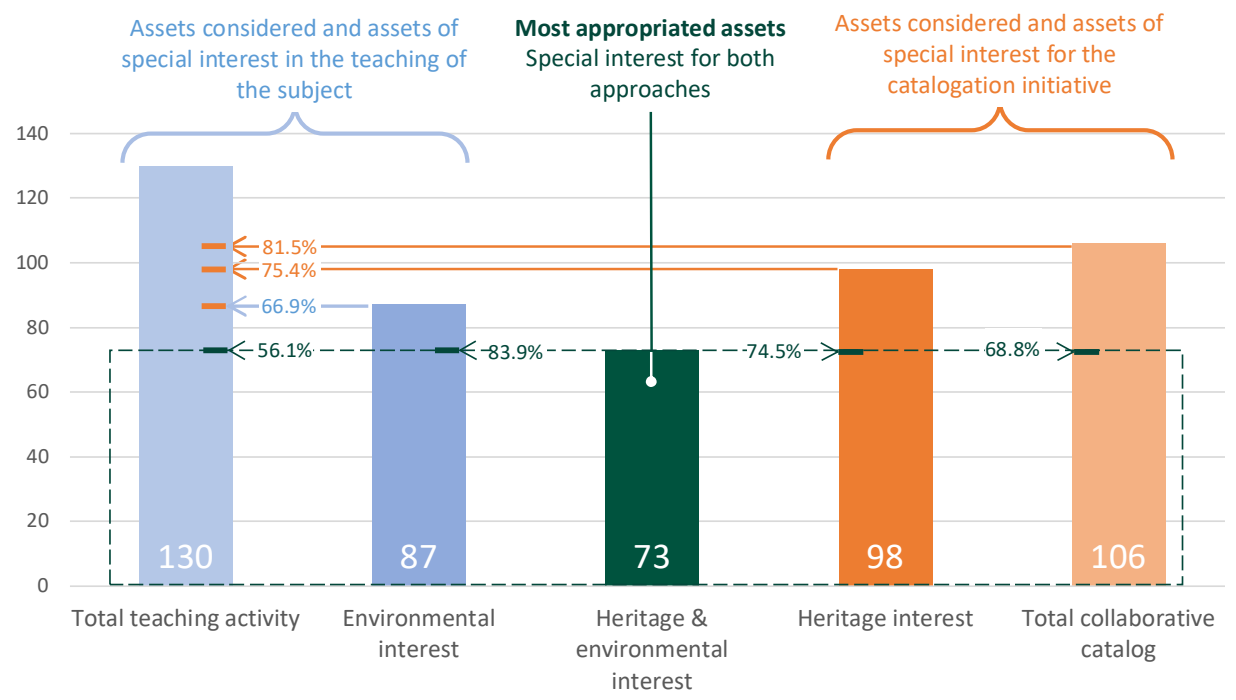

Figure 12. Presence of environmental and heritage values in the assets.

On the other hand, it is possible to identify a set of 73 goods that represent interesting case studies for the proposed practical activity both from the environmental point of view and from the point of view of industrial heritage. These goods are the only ones that really satisfy the characteristics that the goods selected by the students for the activity should have, and, therefore, they are the ones of greatest interest for the students of the next academic years. This group represents a higher percentage within the assets that at least present environmental interest than within the assets that at least present interest as industrial heritage examples. On the other hand, the percentage that this set of assets represents with respect to the 130 considered in the study, $53 \%$, is low, and again it is an aspect that must be corrected for future years by introducing guidelines that help students to properly identify the characteristics requested in the selected case studies. In this sense, it is worth noting some extreme situations, since 19 assets have neither patrimonial interest nor environmental interest, so they represent examples of poor choices of the case study by the students.

Figure 3 showed the number of students corresponding to each academic year and the number of students who carried out the practical activity analyzed in this work. The data available in the virtual courses of each academic year have been analyzed to estimate the impact of this activity on projects for the reuse of industrial heritage in the teaching of the subject. As shown in Figure 1, within the UNED distance education model, activity in the forums is essential. Moreover, in the case of the practical activity analyzed, it is in the forums where the students had to make publications about their reuse project and where the discussion around the proposals is established with the teachers and with the rest of the students. In this way, a first analysis is oriented to the effect of this experience as a catalyst for participation in the forums.

The virtual courses of the subjects taught at UNED usually have at least three types of forums. A forum for communication between students, in which teachers do not participate. A forum for general questions to teachers, both related to the contents and aspects of the operation or logistics of the course, and tutoring group forums, where students can interact with their tutor. The tutor is not the professor of the subject but has a professional profile close to the subject and can help students to address many of its contents, especially in contexts of practical application, as is the case of the activity analyzed in this work.

The Environmental Project Management course, in which the initiative analyzed in this work is contextualized, had in its virtual course all these forums in the 2017-2018 academic year when the practical activity on reuse of industrial assets was proposed for 
the first time. Later, in the 2019-2020 academic year, it was decided to create a specific forum for this activity. Thus, all the orientations and consultations on the activity were concentrated in a single forum. However, in addition, the students were asked to publicly share their work with the rest of the students by creating a specific thread about their work in said forum. In this thread, the rest of the students and the professors could raise doubts, suggestions, and opinions with the author of the work, initiating a discussion about the reuse projects presented by the students and contributing to their collaborative learning.

Table 1 collects the main data related to the activity in these forums during the four courses in which the practical activity has been developed. For each forum and academic course the following information is indicated. The total number of posts in the forum distinguishing between those published by students and those published by professors, and the posts directly related to the practical activity on industrial heritage (CEA-3) indicating the percentage they represent from the total and distinguishing between posts and conversations on a topic.

Table 1. Activity in the subject forums and impact of the practical activity analyzed (CEA-3).

\begin{tabular}{|c|c|c|c|c|c|c|}
\hline \multirow{2}{*}{$\begin{array}{c}\text { Academic } \\
\text { Year }\end{array}$} & \multicolumn{3}{|c|}{ General Consultation Forum } & \multicolumn{3}{|c|}{ About CEA-3 } \\
\hline & Total Posts & Students & Teachers & Posts & Conversations & $\%$ Total Posts \\
\hline 2017-2018 & 220 & 153 & 67 & 40 & 6 & $18.2 \%$ \\
\hline 2018-2019 & 228 & 148 & 80 & 42 & 9 & $18.4 \%$ \\
\hline 2019-2020 & 130 & 89 & 41 & 2 & 1 & $1.5 \%$ \\
\hline \multirow[t]{3}{*}{$2020-2021$} & 156 & 102 & 54 & 26 & 1 & $16.7 \%$ \\
\hline & \multicolumn{3}{|c|}{ Tutoring Groups Forums } & \multicolumn{3}{|c|}{ About CEA-3 } \\
\hline & Total Posts & Students & Teachers & Posts & Conversations & \% Total Posts \\
\hline 2017-2018 & 57 & 25 & 32 & 14 & 6 & $24.6 \%$ \\
\hline 2018-2019 & 38 & 21 & 17 & 13 & 4 & $34.2 \%$ \\
\hline 2019-2020 & 32 & 12 & 20 & 7 & 3 & $21.9 \%$ \\
\hline \multirow[t]{3}{*}{$2020-2021$} & 31 & 14 & 17 & 7 & 4 & $22.6 \%$ \\
\hline & \multicolumn{3}{|c|}{ Specific Forum for Activity CEA-3 } & \multicolumn{3}{|c|}{ About CEA-3 } \\
\hline & Total Posts & Students & Teachers & Posts & Conversations & $\%$ Total Posts \\
\hline 2017-2018 & - & - & - & - & - & - \\
\hline 2018-2019 & - & - & - & - & - & - \\
\hline 2019-2020 & 165 & 136 & 29 & 165 & 30 & $100.0 \%$ \\
\hline 2020-2021 & 332 & 329 & 3 & 332 & 81 & $100.0 \%$ \\
\hline
\end{tabular}

From the information collected in Table 1, different figures are shown to facilitate the interpretation of these data. Figure 13 shows the messages published during each of the four academic years in which the practical activity on industrial heritage has been developed, distinguishing the publications in three different forums, and also if the messages respond to students or teachers and if they are related with the proposed practical activity. A certain decrease in activity can be observed in the forums of general consultations and tutoring groups, although this phenomenon is accompanied by the activation of a new forum in the last two courses specifically oriented to the practical activity proposed. 


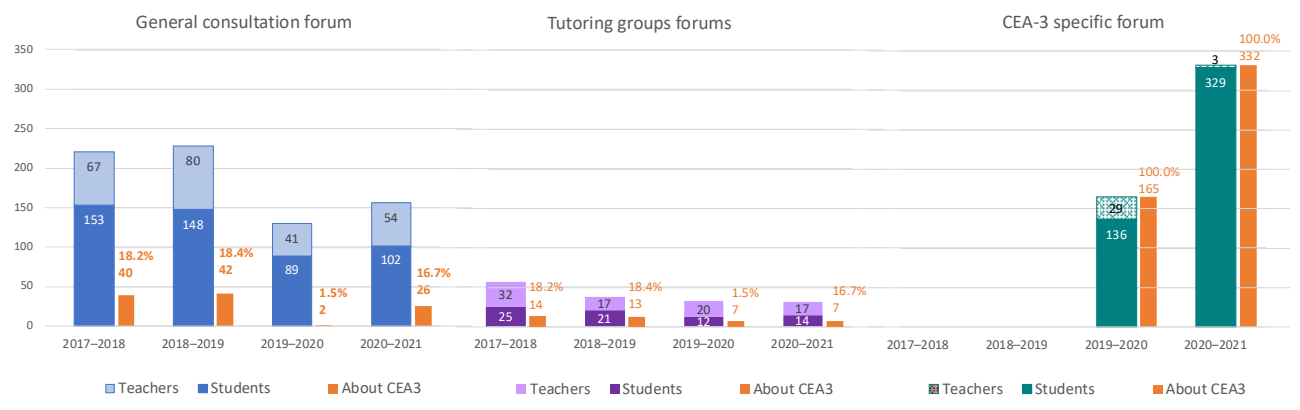

Figure 13. Distribution of the publications made in the forums of the virtual course according to the forum in which they are published, the type of author and the relationship with the CEA-3.

As can be seen in Figure 13, the activity in the forum created specifically to channel the interaction around CEA-3 generates a significant number of publications capable of more than offsetting the downward trend observed in the other forums. In fact, as can be seen in Figure 14, only the 332 messages published in this forum during the 2020-2021 academic year exceeded those published in all the virtual course forums in the 2016-2017 and 2018-2019 academic years, when still this specific forum had not been created. Thanks to this, it can be observed that in the 2020-2021 academic year, the number of global messages in the virtual course practically doubled the values of the first two courses. The second graph in Figure 14 shows how in the two courses in which this specific CEA-3 forum has been active it exceeded $50 \%$ of the messages published in the virtual course forums, reaching in the last year $64 \%$.
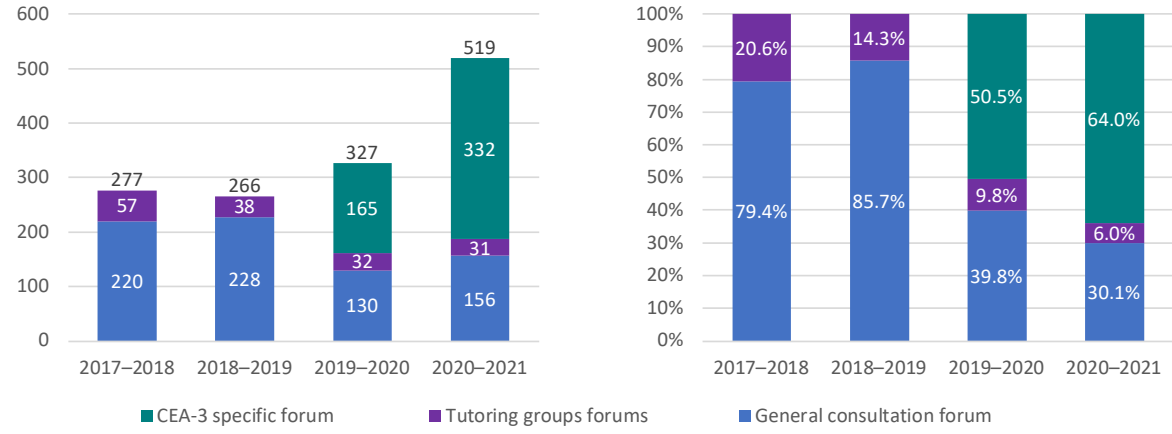

Figure 14. Distribution of the publications made in the forums of the virtual course of the subject according to the forum in which they are published.

These data reinforce the decision to create this specific forum and confirm its positive effect in terms of student participation and interaction with both teachers and other students. On the other hand, the impact of the activity CEA-3 is greater when considering all the forums. As previously mentioned, Table 1 includes the identification of the number of publications related to this activity for each forum and during each academic year. Obviously, in the specific forum of the CEA-3, all the publications are related to the activity. However, the rest of the forums also identify messages about this activity. Figure 15 shows in grey the total messages published each course, considering jointly all the forums, and in orange those related to the activity on reuse of industrial heritage (CEA-3). Both data show a strong upward trend, and the influence of CEA-3 on participation in forums is clear, with publications about it reaching $70.3 \%$ of the messages published in forums during the 2020-2021 academic year. 


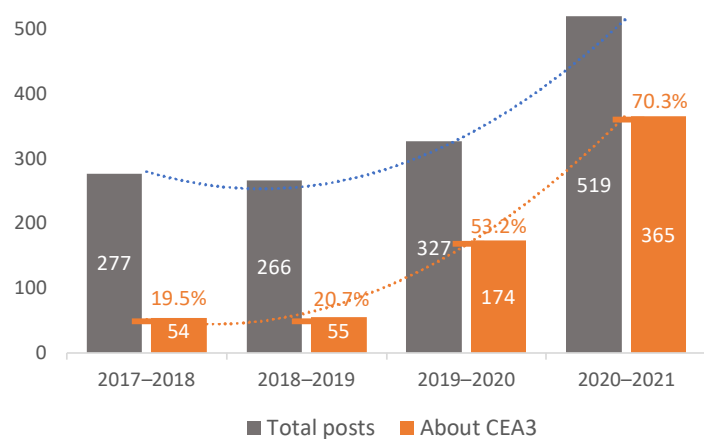

Figure 15. Evolution of total publications in the virtual course forums by academic year and evolution of publications related to CEA-3.

\section{Discussion}

This work analyzes the results derived from an initiative for the cataloging of industrial heritage assets that derives from a teaching activity on their reuse, which is also analyzed. In both contexts, the authors value the results obtained positively.

On the one hand, the number of assets identified through this collaborative cataloging experience is considered relevant, and most of the identified assets were not included in the previous catalogs made available to students as basic references $[60,61,64]$, so that the ability of students to identify new assets in the territories in which they live can be appreciated. Thus, this strategy of collaborative cataloging throughout the territory is considered interesting and especially useful in a typology such as industrial heritage, whose assets sometimes derive from productive activities that ceased a long time ago and which, due to various factors, may be little known outside the local level.

In this sense, the characteristics and geographical distribution of the UNED students and the territorial presence of this university through its structure of Territorial Associated Centers, are considered key aspects to the success of this cataloging initiative. Characteristics that in fact are giving an important role to the UNED in the strategies of reactivation and development at the local level and in the fight against the depopulation of rural areas. The dissemination of heritage contributes to its enhancement and protection, and all this provides new resources to the territories in which these assets are located, for example through the promotion of industrial tourism $[12,13]$. Therefore, from this point of view, collaborative cataloging initiatives such as the one described can make their small contribution to the development of different territories.

On the other hand, at the teaching level, the practical activity around industrial heritage proposed to students has had a positive impact on their participation in the subject, and on the motivation of the students, allowing a context in which it is possible to build knowledge together [47]. Communication between the students themselves and with the teachers about the proposed activity is considered very beneficial from the educational point of view $[49,50]$. The discussion generated around the projects developed by the students is considered especially interesting. This collaborative learning experience has been successful for both students and teachers and has allowed great interaction, something that is not always easy in distance education contexts. Thus, it has been possible to apply strategies aligned with the approaches defined by the EHEA for teaching project subjects [51,53], and also contribute to the Sustainable Development Goals of the European Union [59], specifically in relation to Goal 4 (Quality Education) and Goal 11 (Sustainable Cities and Societies).

In addition, thanks to this approach, the participation of students in the activity based on industrial heritage assets, supposes their contact with this typology. However, not only through the case study selected by each student, but also through the assets studied by the rest of the students, which provides varied examples and allows a greater knowledge of the typology. The subsequent integration of the identified assets in the collaborative catalog, and in some cases also the integration of the video presentations of the projects 
carried out by the students, offers a greater diffusion to the identified assets. In addition, collaborative initiatives have another advantage, since all collaborators will also contribute to the dissemination of collective results, in this case, sharing and promoting the online collaborative catalog. Since the open publication of the collaborative catalog on the UNED Industrial Heritage Team Blog [73] on 2 July 2021, the map that collects the identified assets has received more than 2600 visits [76].

At the same time, the projects shared in the online collaborative catalog by some students show examples of reuse initiatives that can serve as a stimulus for external users of the catalog in order to understand the role that these assets can play in the sustainable development of the territory $[8,9]$ and also to assume active roles in proposing new uses beneficial for citizens [24,25] and in monitoring [25] and disseminating these kinds of assets.

With all this, the collaborative experiences described, both the teaching and the cataloging, are considered interesting and positive and will remain in the future courses. However, the study carried out has made it possible to identify some deficiencies on which to act. Specifically, complementary guidelines should be included to reduce the number of assets selected by students that lack environmental interest, heritage interest, or both.

Finally, the authors consider this initiative easily exportable to other subjects in the Engineering Projects area of knowledge in which they teach and in which the contents of industrial heritage can be attractive. This would mean a greater participation of students in the initiative, or it could also allow the launching of other collaborative initiatives oriented to other typologies and themes. In this way, and given the positive results obtained in this experience, it is considered interesting to continue this line of research in teaching innovation through collaborative strategies and to continue exploring the opportunities that these approaches can offer in the promotion of industrial heritage.

Author Contributions: Conceptualization, J.C.; methodology, J.C., A.G.-D. and M.A.S.; software, J.C. and A.G.-D.; validation, J.C., A.G.-D. and M.A.S.; formal analysis, J.C., A.G.-D. and M.A.S.; investigation, J.C. and A.G.-D.; resources, J.C., A.G.-D. and M.A.S.; data curation, A.G.-D. and J.C.; writing-original draft preparation, J.C. and A.G.-D.; writing-review and editing, J.C. and M.A.S.; visualization, J.C. and A.G.-D.; supervision, J.C. and M.A.S.; project administration, J.C. and M.A.S.; funding acquisition, M.A.S. and J.C. All authors have read and agreed to the published version of the manuscript.

Funding: This research was funded with resources from the Postgraduate Program and Master on Analysis, Management and Projects in Industrial Heritage (Análisis, Gestión y Proyectos en Patrimonio Industrial), which is taught at the UNED and in which the authors collaborate.

Institutional Review Board Statement: Not applicable.

Informed Consent Statement: Not applicable.

Data Availability Statement: Not applicable.

Acknowledgments: The authors thank the students of the Environmental Projects Management course, of the Degree in Environmental Sciences of the UNED, for their participation in the practical activity on reuse of industrial heritage assets, from which the collaborative cataloging initiative exposed in this paper derives. The authors would like to especially thank the collaboration of the students who voluntarily shared the presentation of their work in the collaborative catalog.

Conflicts of Interest: The authors declare no conflict of interest.

\section{References}

1. Frisch, M. De-, Re-, and Post-Industrialization: Industrial Heritage as Contested Memorial Terrain. J. Folk. Res. 1998, 35, 241-249.

2. Muehlebach, A. The Body of Solidarity: Heritage, Memory, and Materiality in Post-Industrial Italy Since. Comp. Stud. Soc. Hist. 2021, 59, 96-126. [CrossRef]

3. Cossons, N. Why preserve the industrial heritage? In Industrial Heritage Re-Tooled: The TICCIH Guide to Industrial Heritage Conservation; Douet, J., Ed.; Routledge: New York, NY, USA, 2015; pp. 6-16. ISBN 978-1-62958-203-0. 
4. Del Pozo, P.B.; González, P.A. Industrial Heritage and Place Identity in Spain: From Monuments to Landscapes. Geogr. Rev. 2012, 102, 446-464. [CrossRef]

5. Benito del Pozo, P. Territorio, paisaje y herencia industrial: Debates y acciones en el contexto europeo. Doc. Anàl. Geogr. 2012, 58, 443. [CrossRef]

6. Falconer, K. Industrial and engineering heritage in Europe, 50 winners of the European Heritage Awards/Europa Nostra Awards. Ind. Archaeol. Rev. 2021, 43, 76-77. [CrossRef]

7. Oevermann, H. Good practice for industrial heritage sites: Systematization, indicators, and case. J. Cult. Herit. Manag. Sustain. Dev. 2020, 10, 157-171. [CrossRef]

8. De Gregorio, S.; De Vita, M.; De Berardinis, P.; Palmero, L.; Risdonne, A. Designing the Sustainable Adaptive Reuse of Industrial Heritage to Enhance the Local Context. Sustainability 2020, 12, 9059. [CrossRef]

9. Guo, P.; Li, Q.; Guo, H.; Li, H. Quantifying the core driving force for the sustainable redevelopment of industrial heritage: Implications for urban renewal. Environ. Sci. Pollut. Res. 2021, 28, 48097-48111. [CrossRef]

10. Bottero, M.; D'Alpaos, C.; Oppio, A. Ranking of adaptive reuse strategies for abandoned industrial heritage in vulnerable contexts: A multiple criteria decision aiding approach. Sustainability 2019, 11, 785. [CrossRef]

11. Somoza-Medina, X.; Monteserín-Abella, O. The sustainability of industrial heritage tourism far from the axes of economic development in Europe: Two case studies. Sustainability 2021, 13, 1077. [CrossRef]

12. Pardo Abad, C.J. Valuation of industrial heritage in terms of sustainability: Some cases of tourist reference in spain. Sustainability 2020, 12, 9216. [CrossRef]

13. Beretić, N.; Talu, V.; Cecchini, A. Emergency-proof tourism: The heritage of industrial archaeology in internal areas as a potential for a sustainable tourism. Sustainability 2021, 13, 3911. [CrossRef]

14. Perfetto, M.C.; Vargas-Sánchez, A. Towards a Smart Tourism Business Ecosystem based on Industrial Heritage: Research perspectives from the mining region of Rio Tinto, Spain. J. Herit. Tour. 2018, 13, 528-549. [CrossRef]

15. Jones, C.; Munday, M. Blaenavon and United Nations World Heritage Site Status: Is Conservation of Industrial Heritage a Road to Local Economic Development? Reg. Stud. 2001, 35, 585-590. [CrossRef]

16. Xie, P.F. A life cycle model of industrial heritage development. Ann. Tour. Res. 2015, 55, 141-154. [CrossRef]

17. Rautenberg, M. Industrial heritage, regeneration of cities and public policies in the 1990's: Elements of a French/British comparison. Int. J. Herit. Stud. 2012, 18, 513-525. [CrossRef]

18. Orange, H. Industrial Archaeology: Its Place Within the Academic Discipline, the Public Realm and the Heritage Industry. Ind. Archaeol. Rev. 2008, 30, 83-95. [CrossRef]

19. Álvarez-Areces, M.Á.; Comité Internacional para la Salvaguarda del Patrimonio Industrial; Ticcih-España. Industrial Heritage. A Future for the Past from a European Perspective. Apunt. Rev. Estud. sobre Patrim. Cult. 2018, 21, 6-25.

20. Ifko, S. Comprehensive Management of Industrial Heritage Sites as A Basis for Sustainable Regeneration. Procedia Eng. 2016, 161, 2040-2045. [CrossRef]

21. Xie, P.F.; Lee, M.Y.; Wong, J.W.-C. Assessing community attitudes toward industrial heritage tourism development. J. Tour. Cult. Chang. 2020, 18, 237-251. [CrossRef]

22. Firth, T.M. Tourism as a means to industrial heritage conservation: Achilles heel or saving grace? J. Herit. Tour. 2011, 6, 45-62. [CrossRef]

23. Yuan, Q.; Song, H.; Chen, N.; Shang, W. Roles of Tourism Involvement and Place Attachment in Determining Residents' Attitudes Toward Industrial Heritage Tourism in a Resource-Exhausted City in China. Sustainability 2019, 11, 5151. [CrossRef]

24. Oevermann, H.; Degenkolb, J.; Dießler, A.; Karge, S.; Peltz, U. Participation in the reuse of industrial heritage sites: The case of Oberschöneweide, Berlin. Int. J. Herit. Stud. 2016, 22, 43-58. [CrossRef]

25. Gao, M.; Tian, Y. Construction of Public Participation Cloud Platform for industrial heritage protection under the background of smart city. In Proceedings of the 2020 International Conference on Artificial Intelligence and Computer Engineering (ICAICE), Beijing, China, 23-25 October 2020; pp. 124-129. [CrossRef]

26. Zhang, J.; Cenci, J.; Becue, V.; Koutra, S.; Ioakimidis, C.S. Recent evolution of research on industrial heritage in Western Europe and China based on bibliometric analysis. Sustainability 2020, 12, 5348. [CrossRef]

27. Claver, J.; García-Domínguez, A.; Sebastián, M.A. Decision-Making Methodologies for Reuse of Industrial Assets. Complexity 2018, 2018. [CrossRef]

28. Claver, J.; García-Domínguez, A.; Sebastián, M.A. Multicriteria decision tool for sustainable reuse of industrial heritage into its urban and social environment. Case studies. Sustainability 2020, 12, 7430. [CrossRef]

29. Liu, F.; Zhao, Q.; Yang, Y. An approach to assess the value of industrial heritage based on Dempster-Shafer theory. J. Cult. Herit. 2018, 32, 210-220. [CrossRef]

30. Berta, M.; Bottero, M.; Ferretti, V. A mixed methods approach for the integration of urban design and economic evaluation: Industrial heritage and urban regeneration in China. Environ. Plan. B Urban Anal. City Sci. 2018, 45. [CrossRef]

31. Congress on the European Architectural Heritage. The Declaration of Amsterdam; Congress on the European Architectural Heritage: Amsterdam, The Netherlands, 1975.

32. TICCIH. The Nizhny Tagil Charter for the Industrial Heritage; Adopted at the Triennial National Assembly of TICCIH; TICCIH: Moscow, Russia, 2003. 
33. Oglethorpe, M.; McDonald, M. Recording and documentation. In Industrial Heritage Re-Tooled: The TICCIH Guide to Industrial Heritage Conservation; Douet, J., Ed.; Routledge: New York, NY, USA, 2015; pp. 55-62. ISBN 978-1-62958-203-0.

34. Rossnes, G. Process recording. In Industrial Heritage Re-Tooled: The TICCIH Guide to Industrial Heritage Conservation; Douet, J., Ed.; Routledge: New York, NY, USA, 2015; p. 63. ISBN 978-1-62958-203-0.

35. Claver, J.; García-Domínguez, A.; Sevilla, L.; Sebastián, M.A. A multi-criteria cataloging of the immovable items of industrial heritage of Andalusia. Appl. Sci. 2019, 9, 275. [CrossRef]

36. Masi, M.; Vecchio, Y.; Pauselli, G.; Di Pasquale, J.; Adinolfi, F. A Typological Classification for Assessing Farm Sustainability in the Italian Bovine Dairy Sector. Sustainability 2021, 13, 7097. [CrossRef]

37. Valenzuela-Venegas, G.; Salgado, J.C.; Díaz-Alvarado, F.A. Sustainability indicators for the assessment of eco-industrial parks: Classification and criteria for selection. J. Clean. Prod. 2016, 133, 99-116. [CrossRef]

38. Merciu, F.-C.; Merciu, G.-L.; Cercleux, A.-L.; Drăghici, C.C. Conversion of Industrial Heritage as a Vector of Cultural Regeneration. Procedia-Soc. Behav. Sci. 2014, 122, 162-166. [CrossRef]

39. Janney, K. Collaborative Cataloging. J. Internet Cat. 2005, 7, 33-48. [CrossRef]

40. Mugridge, R. Cooperative Cataloging: Shared Effort for the Benefit of All; Routledge: New York, NY, USA, 2012; ISBN 978-0-415-68973-1.

41. Keenan, T.M.; Burroughs, J.M.; Ebanues, S. Partners in Collaborative Cataloging: The U.S. Government Printing Office and the University of Montana. Cat. Classif. Q. 2013, 51, 118-128. [CrossRef]

42. Loren-Méndez, M.; Pinzón-Ayala, D.; Ruiz, R.; Alonso-Jiménez, R. Mapping heritage: Geospatial online databases of historic roads. The case of the N-340 roadway corridor on the Spanish mediterranean. ISPRS Int. J. Geo-Inf. 2018, 7, 134. [CrossRef]

43. Gallwey, J.; Eyre, M.; Tonkins, M.; Coggan, J. Bringing lunar LiDAR back down to earth: Mapping our industrial heritage through deep transfer learning. Remote Sens. 2019, 11, 1994. [CrossRef]

44. Rojas-Sola, J.I.; López-García, R. Computer-aided design in the recovery and analysis of industrial heritage: Application to a watermill. Int. J. Eng. Educ. 2007, 23, 192-198.

45. Torrecillas, C.; García, L.; Valderrama-Gual, F. The use of industrial heritage for 3D design learning. In Proceedings of the 12th Annual International Conference of Education, Research and Innovation (ICERI), Seville, Spain, 11-13 November 2019; pp. 5704-5713.

46. Suárez, J.; Rojas-Sola, J.I.; Rubio, R.; Martín, S.; Morán, S. Teaching Applications of the New Computer-Aided Modelling Technologies in the Recovery and Diffusion of the Industrial Heritage. Comput. Appl. Eng. Educ. 2009, 17, 455-466. [CrossRef]

47. Lenkauskaitè, J.; Colomer, J.; Bubnys, R. Students' Social Construction of Knowledge through Cooperative Learning. Sustainability 2020, 12, 9606. [CrossRef]

48. UNESCO Education for Sustainable Development. Available online: https://en.unesco.org/themes/education-sustainabledevelopment (accessed on 25 August 2021).

49. Colomer, J.; Cañabate, D.; Stanikūnienè, B.; Bubnys, R. Formulating Modes of Cooperative Learning for Education for Sustainable Development. Sustainability 2021, 13, 3465. [CrossRef]

50. Rocca, C.L.; Margottini, M.; Capobianco, R. Collaborative Learning in Higher Education. Open J. Soc. Sci. 2014, 02, 61-66. [CrossRef]

51. Bologna Process Secretariat European Higher Education Area and Bologna Process. Available online: https://www.ehea.info/ (accessed on 14 September 2021).

52. Hernández-Pina, F.; Martinez-Clares, P.; Martínez-Juñarez, M.; Monroy Hernández, F. Learning and competences: A new view. Rev. Esp. Orientac. Psicopedag. 2009, 20,312-319.

53. Blanco, M.; Gonzalez, C.; Sanchez-Lite, A.; Sebastian, M.A. A Practical Evaluation of a Collaborative Learning Method for Engineering Project Subjects. IEEE Access 2017, 5, 19363-19372. [CrossRef]

54. Cendón, J.A.; Limas, M.C.; Fernández, L. Prototype developmentas tools for collaborative learning in project engineering in the context of the ESHE framework. In Proceedings of the 17th International Congress on Project Management Engineering, Logroño, Spain, 17-19 July 2013; AEIPRO: Valencia, Spain, 2013; pp. 1812-1820.

55. Blasco, J.; Estay-Niculcar, C.A.; Cistero, J. Teaching of projects with an operational focus and an ophthalmological and virtual environment: Results of our experience and suggestions Futures. In Proceedings of the 6th International Congress on Project Engineering, Barcelona, Spain, 23-25 October 2002; AEIPRO: Valencia, Spain, 2002.

56. Martinez-Mones, A.; Gomez-Sanchez, E.; Dimitriadis, Y.A.; Jorrin-Abellan, I.M.; Rubia-Avi, B.; Vega-Gorgojo, G. Multiple case studies to enhance project-based learning in a computer architecture course. IEEE Trans. Educ. 2005, 48, 482-489. [CrossRef]

57. Martín Del Peso, M.; Rabadán Gómez, A.B.; Hernández March, J. Mismatches between Higher Education and the Labour Market in Engineering Sciences: The Employers' Point of View in the Region of Madrid. Rev. Educ. 2013, 244-267. [CrossRef]

58. Agredo-Delgado, V.; Ruiz Melenje, P.H.; Collazos, C.A.; Moreira, F.; Fardoune, H.M. Methodological Guidelines Catalog to Support the Collaborative Learning Process. Educ. Knowl. Soc. 2020, 21. [CrossRef]

59. United Nations Sustainable Development Goals to Transform Our World. Available online: https://www.un.org/ sustainabledevelopment/ (accessed on 25 August 2021).

60. Institute of the Cultural Heritage of Spain (IPCE), Ministry of Culture and Sport, Spanish Government. National Plan of Industrial Heritage. Available online: https://www.culturaydeporte.gob.es/planes-nacionales/dam/jcr:b34f01e5-c3d9-497b-bc7a-ecba1 ac65d22/04-industrial-eng.pdf (accessed on 14 July 2021). 
61. Biel-Ibáñez, P.; Cueto, A. 100 Elementos de Patrimonio Industrial en España; Calidad Gráfica SL; TICCIH España, IPCE, CICEES, Eds.; TICCIH España: Gijón, Spain, 2011; ISBN 9788493773861.

62. Tostóes, A.; García-Braña, C.; Landrove, S. (Eds.) La Arquitectura de la Industria, 1925-1965. Registro Docomomo Ibérico; Fundación DOCOMOMO Ibérico: Barcelona, Spain, 2005; ISBN 84-609-1196-9.

63. Claver, J. Methodology for the Analysis and Interpretation of the Assets of the Spanish Industrial Heritage. Application to the Study of the Assets of the Autonomous Community of Madrid. Ph.D. Thesis, Universidad Nacional de Educación a Distancia, Madrid, Spain, 2016.

64. Claver, J.; Sebastián, M.Á. Aproximación y Propuesta de Análisis del Patrimonio Industrial Inmueble Español; Editorial UNED: Madrid, Spain, 2016; ISBN 978-84-362-7166-9.

65. Saaty, T.L. A scaling method for priorities in hierarchical structures. J. Math. Psychol. 1977, 15, 234-281. [CrossRef]

66. Claver-Gil, J.; Sebastián-Pérez, M.Á.; Sevilla-Hurtado, L. Methodology for the study of the industrial heritage. Application to the Autonomous Community of Andalusia. Dyna 2016, 91. [CrossRef]

67. Claver, J.; Sebastián, M.A. Methodological study and characterization of the industrial heritage of the Autonomous Community of Galicia. Procedia Manuf. 2017, 13, 1305-1311. [CrossRef]

68. Claver, J.; Sebastián, M.Á.; Marcos-Bárcena, M.; Sevilla, L. Identificación y caracterización del patrimonio industrial de fabricación en la provincia de Cádiz. Aplicación de metodologías de identificación y clasificación de bienes Resumen. In Proceedings of the 24th CUIEET, Cádiz, Spain, 21-23 September 2016.

69. Claver, J.; Sebastián, M.Á. Methodological proposes for the study of industrial assets. Application to the Province of Huelva. In Proceedings of the 1st International Congress on Industrial Heritage and Public Work, Huelva, Spain, 26-28 October 2016.

70. Claver, J.; Sebastián, M.Á. Methodological analysis of the assets of the industrial heritage in the Autonomous Community of the Region of Murcia. In Proceedings of the 20th International Congress on Project Management and Engineering, Cartagena, Spain, 13-15 July 2016.

71. UNED. Website of the Environmental Project Management Course. Available online: http://portal.uned.es/portal/ page?_pageid=93,71398207\&_dad=portal\&_schema=PORTAL\&idAsignatura=61014157\&idTitulacion=6101 (accessed on 10 August 2021).

72. European Union European Credit Transfer and Accumulation System (ECTS) I Education and Training. Available online: https: / / ec.europa.eu/education/resources-and-tools/european-credit-transfer-and-accumulation-system-ects_en (accessed on 10 August 2021).

73. UNED. Blog of the UNED Industrial Heritage Team. Available online: http://blogs.uned.es/patrimonioindustrial/ (accessed on 13 August 2021).

74. UNED. Industrial Production and Manufacturing Engineering Research Group (IPME). Available online: http:/ / portal.uned.es / portal/page?_pageid=93,19770354\&_dad=portal\&_schema=PORTAL (accessed on 13 August 2021).

75. Abad, C.J.P. Application of digital techniques in industrial heritage areas and building efficient management models: Some case studies in Spain. Appl. Sci. 2019, 9, 4420. [CrossRef]

76. UNED. Collaborative Cataloging Teaching Experience-Google My Maps. Available online: https://www.google.com/maps/ d/viewer?mid=11ejcqFoR0XZz9afaixR3BL_WmHIq8r4F\&ll=38.924740845000464\%2C-2.4457305269529206\&z=7 (accessed on 25 August 2021).

77. Google Inc. My Maps. Available online: https://www.google.com/intl/es_ES/maps/about/mymaps/ (accessed on 13 August 2021).

78. UNED. Website of the Analysis, Management and Projects in Industrial Heritage Modular Course. Available online: https: //formacionpermanente.uned.es/tp_actividad/idactividad/12162 (accessed on 28 September 2021). 